\title{
SISI BALAGHAH DALAM TAFSIR AL-BAIDHAWY
}

HADI YASIN MA.

hadiyasin.fai@uia.ac.id

\begin{abstract}
Abstrak
Tulisan ini bermaksud mengungkap tentang sisi Balaghah dalam Tafsir Al-Baidhawy. Seperti kita maklum bahwa sebuah karya Tafsir, dapat dilihat dari beberapa segi, misalnya dari sisi kebahasaannya, sisi penjelasan tentang hukum-hukum atau fikihnya, dari sisi metode penjelasannya apakah tahlily atau Maudhu'i dan lain sebagainya. Bahkan dari kebahasaan-nya saja juga masih bisa dilihat dan dirinci pada beberapa sisi, seperti sisi Nahwu dan Sharf nya, atau dari sisi Balaghahnya.

Penelitian dari sisi Balaghah sebuah karya Tafsir menjadi menarik karena di antara kemukjizatan Al-Quran yang sangat menonjol adalah sisi Balaghah dari Al-Qur an itu sendiri yang tidak dapat ditandingi oleh siapapun dan oleh manusia manapun. Inilah makna I'jaz AlQur an, atau "kemampuan untuk mengalahkan dan melemahkan yang tidak dapat dilawan" dari Al-Quran.
\end{abstract}

Kata kunci : Sisi Balaghah, Tafsir Al-Baidhwy.

\section{A. Pendahuluan}

Salah satu sisi penting dari al-Quran adalah sisi keindahannya, bahkan, keindahan alQuran atau yang dalam istilah bahasa Arab lebih dikenal dengan istilah balaghah, ini merupakan salah satu kekuatan atau mukjizat kebahasaan yang dimiliki Al-Quran. Dan karena ini pulalah, banyak sekali para ulama ahli tafsir senantiasa menyertakan pandanganpandangannya terhadap sisi balaghah dalam Al-Quran. Secara khusus, Al-Qadhi Nashiruddin Abi Sa'id Abdullah Bin Umar Bin Muhammad Bin As-Syirazy Al-Baidhawy, dalam Kitab Anwarut Tanzil Wa Asrarul Ta'wil, atau yang lebih dikenal dengan nama Tafsir Al-Baidhawi ini memang tidak membahas panjang lebar, namun penjelasan sisi balaghah-nya seolah menyatu di dalam kalimat demi kalimat yang beliau sampaikan.

Pertanyaannya adalah, Sepenting apakah Tafsir Al-Baidhawy di kalangan ulama tafsir, dan seperti Al-Baidhawy mengungkap sisi Balaghah Al-Quran di dalam Tafsirnya ?

Al-Imam Al-Hafidz, Abul Fida', Islmail bin Umar : Ibnu Katsir, mengatakan; "Pada tahun 685 H, di antara karya terpenting Al-Baidhawy adalah Kitab Al-Manhaj wa Syarahahu dalam bidang Ushul Fiqh, Kitab At-Thawali' dalam bidang Ushuluddin (ilmu Tauhed), dan kitab Anwarut Tanzil wa Asrarut Takwil dalam bidang Tafsir, Itulah yang sampai pada kita sekarang. Ketiga kitab ini termasuk kitab2 yang popular dan favorit di kalangan ulama ahli ilmu" 1 
Karya Tafsir Al-Baidhawy sebagai salah seorang icon ahli tafsir terkemuka dalam dunia islam, karya dan posisinya menjadi sangat penting .

Theory. 1 atau 2 teory, pro - kontra

Metode, (Tematik)

Sisi Balaghah dalam Anwarut Tanzil wa Asrarut Takwil karya Al-Baidhawy memang ada dan tidak terlalu ditonjolkan, itupun menyatu ke dalam pembahasan dan penafsiran ayat demi ayat dalam Al-Quran.

\section{B. Ilmu Balaghah}

Pertama: Pengertian Balaghah

Istilah “'Ilm Al-Balaghah" terdiri atas dua kata, yaitu 'ilm dan al-Balaghah. Kata “ "Ilm" dapat ditujukan sebagai nama suatu bidang tertentu. Kata "Ilm" juga diartikan sebagai materi-materi pembahasan dalam kajian suatu disiplin ilmu (al-Qadhaya allati tubhatsu fihi). Kata "ilm" berarti 1 pengetahuan tentang suatu bidang yang disusun secara bersistem menurut metode tertentu, yg dapat digunakan untuk menerangkan gejala tertentu di bidang (pengetahuan) itu: dia memperoleh gelar doktor $\mathrm{dl}$-- pendidikan; $\mathbf{2}$ pengetahuan atau kepandaian (tt soal duniawi, akhirat, lahir, batin, dsb);2 Jadi Kata Ilmu juga dapat diartikan sebagai pemahaman yang dimiliki oleh seseorang tentang materi kajian dalam suatu bidang tertentu.

Sedangkan kata "al-Balaghah" didefinisikan oleh para ahli dalam bidang ini dengan definisi yang beragam, diantaranya adalah:

1) Menurut Ali Jarim dan Musthafa Amin dalam Balaghatul Wadhihah:

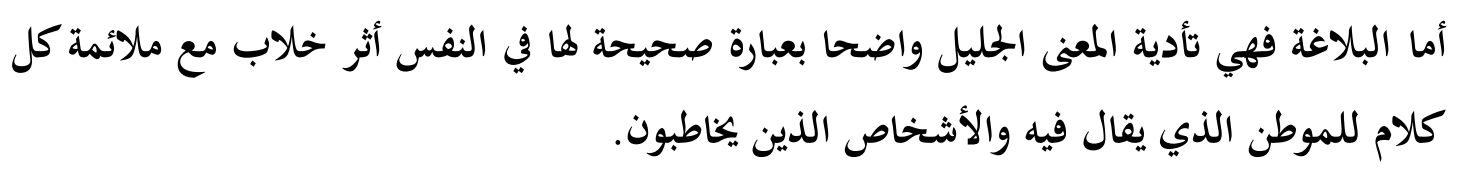

"Adapun Balaghah itu adalah mengungkapkan makna yang estetik dengan jelas mempergunakan ungkapan yang benar, berpengaruh dalam jiwa, tetap menjaga relevansi setiap kalimatnya dengan tempat diucapkannya ungkapan itu, serta memperhatikan kecocokannya dengan pihak yang diajak bicara”.3

2) Menurut Dr. Abdullah Syahhatah :

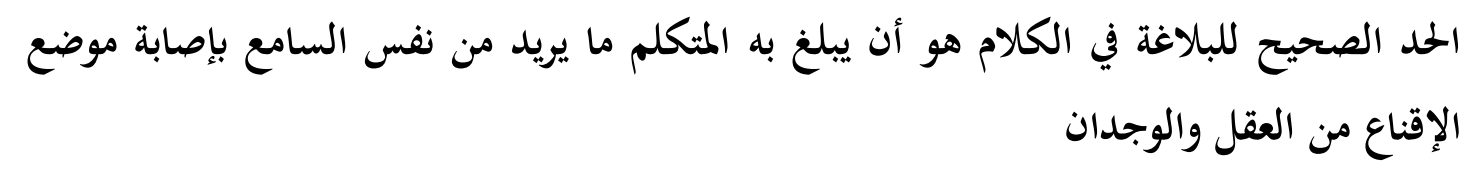

"Definisi yang benar untuk term Balaghah dalam kalimat adalahkeberhasilan si pembicara dalam menyampaikan apa yang dikehendakinya ke dalam jiwa pendengar

2 Kamus besar bahasa Indonesia Elektronik

3 Al balaghah Al-Wadhihah, Ali Jarim dan Musthafa Amin dalam Balaghatul Wadhihah, al maktabah Al-Syamilah 
(penerima), dengan tepat mengena ke sasaran yang ditandai dengan kepuasan akal dan perasaannya". ${ }^{4}$

Dari dua definisi di atas, dapat ditarik suatu pengertian bahwa inti dari Balaghah adalah penyampaian suatu pesan dengan menggunakan ungkapan yang fasih, relevan antara lafal dengan kandungan maksudnya, tetap memperhatikan situasi dan kondisi pengungkapannya, menjaga kepentingan pihak penerima pesan, serta memiliki pengaruh yang signifikan dalam diri penerima pesan tersebut.

Ilmu Balaghah berarti suatu kajian yang berisi teori-teori dan materi-materi yang berkaitan dengan cara-cara penyampaian ungkapan yang bernilai Balaghah itu sendiri.

Ilmu Balaghah adalah ilmu yang mempelajari tentang bagaimana mengolah kata atau susunan kalimat bahasa arab yang indah namun memiliki arti yang jelas, selain itu gaya bahasa yang harus digunakan juga harus sesuai dengan situasi dan kondisi. Para ahli balaghah sepakat membagi ruang lingkup pembahasan ilmu balaghah menjadi tiga ilmu yang masing-masing berdiri sendiri dengan pembahasannya, yaitu: ilmu ma'ani, ilmu bayan dan ilmu badi'.

\section{Ilmu Balaghah Dalam Perspektif Sejarah}

\section{1). Balaghah Pra Turunnya Al-Qur'an}

Kelahiran dan pertumbuhan Balaghah dikalangan masyarakat penggunanya bersifat arbitrer. Orang-orang Arab Jahiliyah pra turunnya al-Qur'an telah dikenal sebagai ahli sastra yang kompeten. Mereka mampu menggubah lirik-lirik sya'ir atau bait-bait puisi yang mempesona yang menunjukkan kesadaran dan keahlian mereka dalam bidang sastra yang bernilai tinggi. Perhatikanlah misalnya apa yang diungkapkan oleh Imru' al-Qays 5 salah seorang pujangga Arab Jahiliyah pada saat malam gelap gulita dimana kedua bola matanya sulit terpejam karena mendengar informasi tentang kematian sang ayah yang sangat dicintainya :

\section{فقلت له لما تمطى بصلبه \# وأردف أعجازا وناء بكلكل}

"Maka kukatakan kepadanya (malam) ketika ia menghimpitku dengan segenap tubuhnya dan menyesakkan dadaku dengan perasaan sedih dan duka cita yang tak terucapkan". 6

Duka nestapa dan kesedihan yang begitu abstrak diekspresikan dalam bentuk gaya bahasa yang figurative dan indah sekali. Keindahan bahasa puisi tersebut jelas dan terasa sekali pada kemampuan si penggubahnya dalam menggambarkan hal-hal yang bersifat abstrak menjadi kongkrit, hingga seakan-akan dapat diraba keberadaannya.

\footnotetext{
4 Dr. Abdullah Syahatah, Ulumut Tafsir, Dar As- Syuruq, Kairo, 2001, Hal 81

5. Imri'il Qais adalah tokoh penyair Jahiliyah yang merintis pembagian bab dan macam-macam syair. Ia di lahirkan pada tahun 130 sebelum Hijriyah.dan ia wafat pada tahun 80 sebelum hijriyah. Lihat Ali al-Jarim \& Musthafa Amin, Dalam AlBalaghah al-Wadhihah, (Kairo: Dar al-Ma'arif, 1951),hlm.7.
} 
Dan resapi serta renungkanlah betapa indahnya gubahan beberapa lirik syai'r yang begitu puitis dalam menggambarkan keadaan yang dialami oleh penyair tatkala ia merasa begitu tersiksa secara psikis dan mental akibat rindu yang begitu mendalam terhadap sang kekasih yang sangat dicintainya. Namun karena adanya jarak yang menghalangi, maka mereka tidak pernah bisa bersua untuk mengobati kerinduannya. Akhirnya keluarlah dari mulut salah seorang diantara mereka lirik-lirik bait syair yang begitu indah untuk menggambarkan keadaan tersebut.

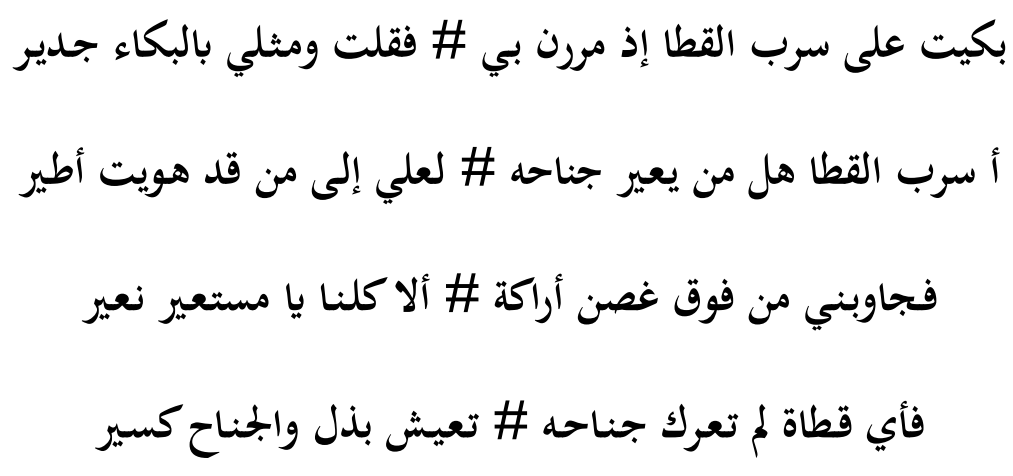

“Aku menangisi sekawanan burung merpati tatkala mereka melintas dihadapanku, \# dan akupun bergumam: orang seperti diriku memang layak untuk menangis.

Wahai kawanan burung merpati, Adakah diantara kalian yang sudi untuk meminjamkan sayapnya kepadaku,\# agar aku dapat terbang tuk menemui kekasih yang kucintai.

Merekapun nyeletuk menjawab permintaanku dari atas ranting pohon arak, Hai orang yang bermaksud meminjam sayap kami, \# ketahuilah bahwa kami juga sebenarnya sekedar dikasih pinjam.

Maka tidak ada seekor burung merpatipun yang rela tuk meminjamkan sayapnya, \# karena( jika itu terjadi) pasti ia akan hidup dalam keadaan hina dan sayapnya akan patah".

Perasaan rindu yang terpendam dan berkecamuk serta perasaan asmara yang bergejolak melahirkan perasaan sedih yang mendalam yang diekspresikan dengan cucuran airmata tertuang dalam gubahan syair tersebut dengan indah sekali. Keadaan tersebut diadukan kepada kawanan burung-dalam bentuk dialog personifikatif-yang dilihat oleh penyair sebagai kelompok makhluk yang beruntung karena dilengkapi dengan sayap yang membuat mereka dapat terbang kemanapun mereka suka. Tidak seperti diri penyair yang terisolir dan nasibnya yang terpasung tidak dapat pergi menemui sang kekasih yang sudah lama didambakannya.

Perkembangan kesusastraan Arab pada era jahiliyah diwarnai oleh adanya perkembangan berbagai bentuk sastra, baik prosa maupun puisi yang dikembangkan oleh orang-orang Arab pada masa itu. Perkembangan tersebut didukung juga oleh adanya berbagai kegiatan yang berlangsung pada musim haji setiap tahunnya, dengan diadakannya berbagai perlombaan pidato dan perlombaan membaca sya'ir, yang diadakan di berbagai pusat kegiatan pada waktu itu, seperti di Suq 'Ukkazh. Kegiatan-kegiatan seperti itu memberi peluang yang besar bagi para ahli sya'ir untuk mengembangkan bahasa dan gaya 
bahasa mereka dengan ungkapan-ungkapan yang menarik, baik dari segi zahir lafal, keindahan kata yang digunakan, maupun kandungan maknanya. ${ }^{7}$

Selanjutnya Ahmad Thib Raya mengutip pernyataan Syauqi Dheif menyatakan bahwa bangsa Arab pada masa jahiliyah tersebut telah mencapai tingkat tinggi dalam menggunakan balaghah dan bayan. ${ }^{8}$ Orang yang melakukan kajian yang serius dan mendalam terhadap sastra Arab jahiliyah, baik prosa maupun puisinya akan berdecak kagum terhadap produkproduk kesusastraan yang mereka miliki. Hal tersebut tampak jelas dari kemampuan mereka untuk mengekspresikan pikiran-pikiran mereka sampai ke tingkat yang lebih tinggi dalam dunia ke-fasih-an dan ke-balaghah-an.

\section{Balagah Pasca Turunnya Al-Qur'an}

Sebagaimana dilihat sebelumnya bahwa keberadaan Balaghah pra turunnya al-Qur'an sudah demikian berkembang, lebih-lebih setelah turunnya al-Qur'an. Keindahan dan kelembutan berbahasa merupakan pokok kajian yang tak habis-habisnya, yang telah melahirkan banyak ungkapan-ungkapan yang indah dan bermakna dalam kepustakaan sastra, terutama setelah turunnya al-Qur'an yang merupakan salah satu inspirator dalam melahirkan keindahan dan kelembutan berbahasa tersebut. ${ }^{9}$

Dalam tradisi Islam, al-Qur'an dipandang sebagai salah satu sumber keindahan atau kebalaghah-an bagi para penyair dan penulis prosa. Al-Qur'an, diakui oleh mereka sebagai puncak balaghah (nahj al-balaghah) dan merupakan model utama (al-namuzaj al-mitsly) dalam rujukan penggubahan syai'r.

Kedudukan al-Qur'an begitu penting dan berpengaruh besar terhadap pola hidup, pola pikir, dan pola tutur umat Islam. Seluruh umat sepakat bahwa salah satu bentuk kemukjizatan al-Qur'an adalah keindahan bahasanya yang tak tertandingi oleh ungkapan manapun. Gagasan tentang nilai keindahan dan keluhuran tradisi sastra al-Qur'an tidak hanya diakui dalam diskursus kesusastraan dan kebahasaan, namun hal tersebut telah menjadi doktrin agama yang mendasar. Otentisitas al-Qur'an didasarkan atas ajaran ketidakmungkinan al-Qur'an untuk dapat ditiru oleh siapapun, baik dari sisi kandungannya, maupun sisi keindahannya. Itulah konsep I'jaz al-Qur'an, kemukjizatan al-Qur'an yang tak tertandingi. Tidak seorangpun manusia yang bisa membuat ungkapan-ungkapan yang serupa dengan al-Qur'an. Bahkan al-Qur'an sendiri selalu mengemukakan tantangan (al-tahaddi) kepada siapa saja yang meragukan otentisitasnya untuk mendatangkan ungkapan yang serupa dengannya walau hanya satu surat saja sebagaimana pernyataan Allah dalam ayat 23 surat alBaqarah :

7 A. Thib Raya, Rasionalitas Bahasa Al-Qur'an, (Jakarta: Fikra, 2006), hlm. 31.

8 A. Thib Raya, Rasionalitas Bahasa Al-Qur'an, (Jakarta: Fikra, 2006), hlm 32

9 George A. Makdisi, Cita Humanisme Islam, terj. A. syamsu Rizal \& Nur Hidayah, (Jakarta: PT. Serambi Ilmu Semesta, 2005), hlm. 228. 


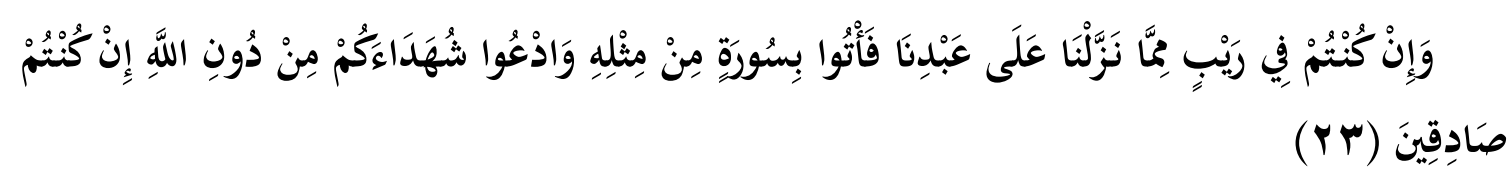

Artinya: "Dan jika kalian masih diselimuti keraguan tentang kebenaran apa (kitab) yang Kami turunkan kepada hamba Kami (Muhammad), maka (coba) datangkanlah sekedar satu surat yang mirip dengannya dan ajaklah para pembantu kalian selain Allah (yang kalian anggap mampu) jika kalian benar-benar jujur”. (QS Al-Baqarah[2]:23)

Dan sesungguhnya mereka telah mengakui dan merasakan ketinggian dan keindahan bahasa al-Qur'an, sehingga diantara mereka ada yang meninggalkan syai'r karena lebih tertarik dengan keindahan bahasa al-Qur'an tersebut sebagaimana keterangan yang diperoleh dari Lubaid dan al-Khansa' dua orang sastrawan dan pujangga besar masa tersebut. Mereka juga berusaha keras untuk mencontoh bahasa Al-Qur'an dan mengembangkan nilai-nilai keindahannya dalam pembicaraan dan penulisan. Bahkan sebagian pakar sastra mencoba dengan sadar dan sekasama untuk menyamai bahkan melampaui keindahan al-Qur'an. Uapaya-upaya tersebut mereka lakukan untuk meladeni tantangan al-Qur'an yang begitu menggugah orang-orang yang memiliki keahlian dan keberanian di antara mereka, meski usaha tersebut tidak pernah berhasil. Tantangan al-Qur'an itu semakin menarik perhatian mereka disamping telah adanya rasa cinta terhadap keindahan dan ketinggian bahasa yang melekat kuat dalam jiwa mereka sejak masa pra turunnya al-Qur'an.10

Pengaruh al-Qur'an terhadap Balaghah 'Arabiyyah tersebut begitu nyata. Hal tersebut ditandai dengan dijadikannya al-Qur'an sebagai objek kajian dalam diskursus-diskursus kebalaghahan yang melahirkan karya-karya besar seperti Kitab Majaz Al-Qur'an karya Abu 'Ubaidah (w. 207 H) yang ditulis karena adanya ketidakpahaman Ibrahim bin Isma'il terhadap penggunaan tasybih dalam penggambaran sifat syajarat al-Zaqqum (makanan penduduk neraka) dalam firman Allah ayat 65 surat al-Shaffat :

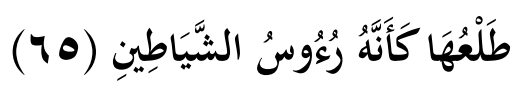

Mayangnya seperti kepala syaitan-syaitan.(QS As-Shaffat[37]:65)

Sampai masa permulaan Islam ini keberadaan ilmu Balaghah sebagai suatu disiplin ilmu yang utuh seperti saat ini belum terkodifikasi, namun ia terus mengalami perkembangan sedikit demi sedikit. Diawali dengan kajian sastra terhadap beberapa sya'ir dan pidato-pidato orang Jahiliah, dilanjutkan dengan mengulas sya'ir dan sastra pada masa awal Islam, sampai kepada masa pemerintahan Daulah Umaiyah, ia terus mengalami perkembangan yang menggembirakan. ${ }^{11}$

Perkembangan Balaghah yang semakin baik tersebut ditandai dengan munculnya para tokoh yang kompeten dan karya-karya besar mereka pada abad ke-III H, seperti Abu 'Ubaidah (w. 211 H), Ibnu Qutaibah (w. 276 H), Ibnu Hasan al-Rumani (w. 284 H), al-Farra' (w.207 H), dan Al-Jahizh (w. 255 H). Abu 'Ubaidah menyusun sebuah kitab tentang Majaz al-Qur'an yang bernama Ilmu Majazil Qur'an. Ibnu Quthaibah menulis kitab Ta'wil Musykil al-Qur'an, dan Al-Farra' menulis kitab Ma'anil Qur'an yang meski kebanyakan berisi kajian

10 George A. Makdisi, Cita Humanisme Islam, terj. A. syamsu Rizal \& Nur Hidayah, (Jakarta: PT. Serambi Ilmu Semesta, 2005), hlm. 226.

11 Abdul Jalal, Ulumul Qur'an, (Surabaya: Dunia Ilmu, 2000), cet. Ke-II. h. 370. 
ilmu Nahwu, tapi juga menyinggung kajian ilmu Balaghah. Sedangkan al-Rumani menyusun kitab An-Naktu Fi I'jazil Qur'an. Dan Al-Jahizh dipandang sebagai tokoh yang sangat berjasa dalam sejarah perkembangan ilmu Balaghah secara umum dan ilmu Bayan secara khusus, lewat karya tulisnya yang berjudul al-Bayan wa al-Tabyin. ${ }^{12}$

Ilmu Balaghah terus mengalami perkembangan sehingga mencapai puncaknya pada abad ke-V H yang ditandai dengan semakin utuhnya kajian-kajian didalamnya yang tertuang dalam dua kitab yang disusun oleh Imam Abdul Qahir al-Jurjani (400-471 H). Kedua kitab tersebut adalah : Pertama, kitab Asrarul Balaghah yang berisi soal-soal majaz, isti'arah, tamtsil, tasybih dan lain-lain dari cabang Ilmu Ma'ani yang merupakan bagian dari Balaghah. Kedua, kitab Dala'ilul I'jaz, yang berisi tentang keindahan susunan kata dan konteksnya, dengan keindahan makna yang merupakan keistimewaan uslub Al-Qur'an yang menunjukkan kemukjizatannya.

Kemudian disusul dengan kemunculan Imam As-Sakaki pada abad ke-VII H yang semakin mematangkan keberadaan Ilmu Balaghah sebagai disiplin Ilmu dengan memetakannya menjadi tiga cabang ilmu sebagai komponennya, yaitu Ilmu Ma'ani, Ilmu Bayan, dan Ilmu Badi'. Namun antara ilmu Bayan dan Ilmu Badi' masih beliau gabung dalam satu ilmu dengan istilah Ilmu al-Mahasin yang terbagi ke dalam dua bagian, yaitu AlMahasin al-Lafziyyah dan Ma'nawiyyah. Beliau menyusun sebuah karya besar yang menguraikan ilmu tersebut disamping ilmu-ilmu pengetahuan bahasa Arab lainnya. Kitab tersebut dikenal dengan nama Miftahul 'Ulum. ${ }^{13}$

Sedangkan pembagian ilmu Balaghah ke dalam tiga istilah (Ilmu Ma'ani, Bayan, dan Badi') seperti yang dikenal sekarang dilakukan oleh Al-Khatib al-Qazwainy (w. 729 H) pada abad ke-VII H dalam karyanya yang bernama Talkhisul Miftah yang merupakan ringkasan dari kitab Miftahul 'Ulum karya As-Sakaki.14

\section{Urgensi Ilmu Balaghah}

Posisi ilmu Balaghah dalam tatanan kelompok ilmu-ilmu Arab persis seperti posisi ruh dari jasad. Keberadaan ilmu Balaghah dan kaidah-kaidah yang tertuang didalamnya sangat urgen. Urgensitas tersebut disebabkan oleh beberapa hal, diantaranya adalah :

1. Ilmu Balaghah merupakan perangkat media yang dapat menghantarkan seseorang kepada pengetahuan tentang ke-I'jaz-an al-Qur'an;

2. Ilmu Balaghah merupakan salah satu instrument yang dapat membantu seorang yang bergelut dengan diskursus al-Qur'an terutama mufassir dalam memahami kandungan isi alQur'an dan pesan-pesan yang tertuang didalamnya. Hal ini diperjelas oleh pernyataan alZamakhsyari dalam al-Kasysyaf :

12 Ahmad Alhasyimi, jawahirul balagah,( Kairo : Muassasah Al-mukhtar, cet.2. 2006) hlm. 5

13 Ahmad Alhasyimi, jawahirul balagah,( Kairo : Muassasah Al-mukhtar, cet.2. 2006) hlm. 5

14 A. Thib Raya, Rasionalitas Bahasa Al-Qur'an, (Jakarta: Fikra, 2006), hlm. 39. 


$$
\begin{aligned}
& \text {...إن أملأ العلوم بما يغمر القرائح وأغضها بما يبهر الألباب القوارح من غرائب نكت يلطف }
\end{aligned}
$$

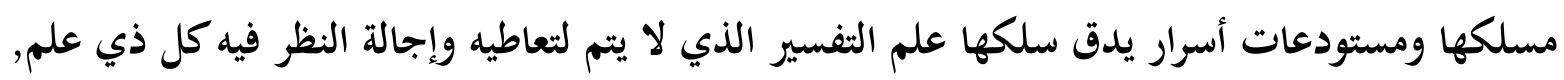

$$
\begin{aligned}
& \text { ولا يغوص على تلك الحقائق إلا رجل قد برع في علمين مختصين بالقرآن, وهما علما المعاني والبيان. }
\end{aligned}
$$

"Sesungguhnya ilmu yang paling sarat dengan noktah-noktah rahasia yang rumit di tempuh, paling padat dengan kandungan rahasia yang pelik, yang membuat watak dan otak manusia kewalahan untuk memahaminya adalah ilmu tafsir, yakni ilmu yang sangat sulit untuk dijangkau dan diselidiki oleh orang yang berstatus alim sekalipun. Dan tidak akan mampu untuk menyelam kekedalaman hakekat pemahaman tersebut kecuali seseorang yang memiliki kompetensi dan kredibilitas dalam dua spesifik ilmu yang berkaitan dengan alQur'an, yaitu ilmu Ma'ani dan ilmu Bayan”.[25]

Dari pernyataan al-Zamakhsyari tersebut, dapat ditangkap pesan utama bahwa ilmu tafsir merupakan ilmu yang sangat sulit dan pelik, sehingga membutuhkan pelbagai perangkat keilmuan yang mendukung dalam upaya pengkajian dan penafsiran al-Qur'an. Salah satu perangkat utama yang mendukung hal tersebut adalah adanya kompetensi dan penguasaan yang matang tentang dua ilmu utama yang berkaitan dengan al-Qur'an, yaitu ilmu Ma'ani dan ilmu Bayan. Penguasaan kedua ilmu ini merupakan prasyarat mutlak bagi siapa saja yang ingin menggali isi al-Qur'an.[26]

Hal tersebut dipertegas oleh Al-Zahabi yang mengutip pernyataan para ulama yang mempersyaratkan beberapa syarat mutlak bagi seorang mufassir dalam upaya menafsirkan al-Qur'an terutama tafsir bi al- ra'yi. Setidaknya mereka harus qualified dan menguasai lima belas jenis ilmu yang merupakan ilmu Bantu mutlak dalam upaya tersebut. Diantara kelima belas ilmu yang mesti dikuasai tersebut adalah ilmu al-Balaghah yang mencakup ketiga komponennya (ilmu Ma'ani, Bayan, dan Badi').[27] Berikut pernyataan Al-Zahabi :

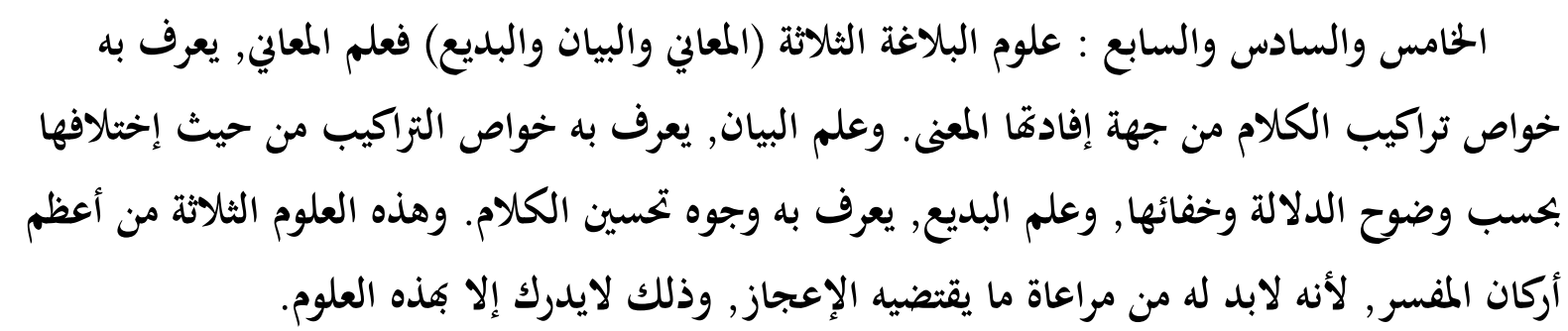

Artinya: "Yang kelima, keenam, dan ketujuh adalah ilmu Balaghah yang mencakup tiga komponen ilmu (Ma'ani, Bayan, dan Badi'). Ilmu Bayan berfungsi sebagai instrument untuk mengetahui karakteristik struktur kalimat dari sisi pemberian makna. Ilmu Bayan berfungsi sebagai instrument untuk mengetahui karakteristik suatu struktur kalimat dalam hal perbedaan bentuk sisi kejelasan atau ketidak jelasan tunjukannya. Sedangkan ilmu Badi' berfungsi sebagai instrument untuk mengenal bentuk-bentuk keindahan suatu ungkapan. Ketiga komponen ilmu ini termasuk bagian yang paling basic yang harus dikuasai oleh seorang mufassir, karena keberadaan seorang mufassir yang dituntut untuk memperhatikan 
sisi kei'jazan al-Qur'an. Hal itu tidak akan terwujud kecuali dia menguasai ketiga komponen ilmu ini". ${ }^{15}$

\section{E. Fungsi Ilmu Balaghah}

Fungsi ilmu Balaghah ini, dalam kaitannya dengan kajian al-Qur'an, setidaknya ada dua fungsi utama yang melekat pada ilmu Balaghah dalam kaitannya dengan kajian ini, yaitu :

\section{1). Fungsi Interpretatif}

Yang dimaksud dengan fungsi interpretatif ini adalah penggunaan ilmu Balaghah dalam menjelaskan dan menerangkan maksud-maksud ayat al-Qur'an. Peranan fungsi ini sangat dominan dalam upaya pengkajian makna-makna teks al-Qur'an, sebagaimana yang dilakukan oleh Abu 'Ubaidah dalam kasus ketidakpahaman Ibrahim bin Ismail tentang maksud uslub tasybih dalam ayat 65 surat al-Shaffat: “طعها كأنه رعوس الثياطين” . Penggunaan uslub tasybih dalam menggambarkan makanan penduduk neraka berupa syajarat al-zaqqum dalam ayat diatas menimbulkan kesulitan dan kerancauan dalam pemahaman bagi setiap orang yang tidak memiliki pengetahuan yang memadai tentang uslub tersebut. Untuk menguraikan interpretasi klausa dalam ayat tersebut sangat dibutuhkan pemahaman yang mendalam tentang ilmu Balaghah. Unsur tasybih dalam klausa ayat tersebut dapat diuraikan sebagai berikut. Dhamir “。” yang melekat pada kata "كأنه" merupakan kata ganti untuk kata "طلع" , yang berposisi sebagai musyabbah. Lafal "كأن" merupakan adat at-tasybih, dan kata "رعوس الثياطين" sebagai musyabbah bih. Sedangkan wajah syabh tidak disebutkan secara eksplisit.

Seorang mufassir yang sangat memperhatikan unsur Balaghah, Imam al-Zamakhsyari dalam menafsirkan maksud ayat tersebut mengawali dengan menjalankan analisnya sesuai dengan analisis ilmu Bayan. Ia menggambarkan mayang pohon zaqqum itu sama dengan kepala-kepala syetan, yang dalam bayang pemikiran manusia sangat menakutkan dan sangat jelek bentuknya. Bayangan kejelekan dan bentuk yang menakutkan itu didasarkan atas keyakinan manusia bahwa setan merupakan makhluk yang paling jahat dan paling menakutkan yang tidak ditemukan padanya sedikitpun kebaikan. Gambaran mengenai mayang pohon zaqqum yang diserupakan dengan kepala-kepala syetan yang begitu menakutkan dan menyeramkan itu hanya ada dalam benak pemikiran manusia saja. Gambaran seperti itu oleh al-Zamakhsyari disebut dengan istilah tasybih takhyili. ${ }^{16}$

\section{Fungsi Argumentatif}

Kata "Argumen" merupakan kata serapan dari bahasa asing dan dalam bahasa Indonesia biasa diartikan dengan alasan yang dapat dipakai untuk memperkuat atau menolak suatu pendapat, pendirian atau gagasan. Dari kata tersebut lahir istilah "Argumentasi", yang berarti pemberian alasan untuk memperkuat atau menolak suatu pendapat, pendiriian, atau gagasan.

15 Imam Al-Dzahabi, Al-Tafsir wal Mufassirun,(Maktabah Mash'ab bin Umair al-Islamiyah, 2004), h. 190-191

16 Al-Zamakhsyari, Al-Zamakhsari, Al-Kasysyaf 'An Haqaiq al-Tanzil Wa 'Uyun al-Aqawil fi Wujuh al-Ta'wil , , jilid III, (Beirut: Dar al-Fikr, 1983)h. 342. Lihat juga keterangannya dalam Ahmad Thib Raya, Rasionalitas Bahasa Al-Qur'an, (Jakarta: Fikra, 2006), h. 205-207 
Sedangkan "Argumentatif" adalah memberikan alasan yang dapat dipergunakan sebagai bukti. ${ }^{17}$

Dari pengertian-pengertian kata yang dikemukakan tersebut dapat ditarik suatu pengertian bahwa yang dimaksud dengan fungsi argumentif ilmu Balaghah adalah suatu fungsi yang dilekatkan bagi ilmu ini dalam upaya memperkuat atau menolak pendapat yang sudah ada tentang al-Qur'an berdasarkan bukti-bukti tertentu. Yang penulis maksud disini adalah pandangan orang yang masih meragukan otentisitas dan keberadaan kitab suci alQur'an yang benar-benar datang dari sisi Allah SWT, bahkan cenderung menuduh bahwa kitab tersebut merupakan gubahan tangan Nabi Muhammad Saw. Bagi orang yang memiliki pengetahuan yang mendalam tentang ilmu Balaghah pasti akan menemukan nilai-nilai sastra yang sangat tinggi yang jauh melebihi kemampuan manusia untuk menggubah dan membuat yang mirip dengannya. Oleh karenanya pengetahuannya tentang ilmu Balaghah tersebut dapat menjadi argument yang mendukung ke-I'jaz-an al-Qur'an yang menunjukkan otentisitas kitab tersebut. Pengetahuan tentang Balaghah itu sekaligus membantah tuduhan dan pandangan orang yang menyangsikan otentisitas al-Qur' an selaku kitab suci yang benarbenar bersumber dari sisi Allah SWT, bukan hasil goresan tangan manusia apalagi seperti sosok Nabi Muhammad Saw yang dikenal dengan sifat ke-ummi-annya.

Oleh karena itu, perhatian terhadap kajian ke-balagh-an ini sudah selayaknya menjadi perhatian serius umat Islam terutama pemerhati kajian dan diskursus al-Qur'an. Bahkan Abu Hilal al-'Askari memandang kedudukan ilmu Balaghah sangat strategis dan utama. Ia menempatkannya dalam urutan kedua setelah ilmu yang berkaitan dengan ma'rifatullah (theology) yang mesti mendapat perhatian serius. Keberadaannya harus dijaga dan dipertahankan lewat pendidikan berkesinambungan. Karena siapa saja yang melalaikan keberadaan ilmu Balaghah pasti ia tidak akan mengetahui sisi kemukjizatan al-Qur'an, baik dari sisi keindahan susunan lafal, keunikan struktur kalimat, maupun keindahan-keindahan lainnya yang berhubungan dengan sisi maknanya. ${ }^{18}$

\section{F. Macam-Macam Ilmu Balaghah}

Sebagaimana disebutkan sebelumnya bahwa dalam kitab Balaghah permulaan, ilmu Balaghah masih belum dipilah kedalam beberapa bagian seperti sekarang ini. Pemilahan ini dirintis oleh Abdul Qahir al-Jurjani, dilanjutkan oleh As-Sakaki, dan dimantapkan lagi oleh Khatib al-Qazwaini. Dalam kitab Talkhisul Miftah yang dikutip oleh Abdul Jalal, beliau menjelaskan macam-macam ilmu Balaghah sebagai berikut: ${ }^{19}$

a). Ilmu Ma'ani, yang membahas segi lafal Arab yang relevan dengan tujuannya. Definisinya yaitu :

17 Tim Penyusun Kamus Pusat Pembinaan dan Pengembangan Bahasa Departemen Pendidikan dan Kebudayaan, Kamus Besar Bahasa Indonesia, (Jakarta: Balai Pustaka, 1989), cet. Ke-2, h. 48.

18 Abd al-'Aziz 'Atiq, 'Ilm al-Bayan, (Beirut: Dar Al-Nahdah al-'Arabiyyah, 1985), h 13

19 Abdul Jalal, Ulumul Qur'an, (Surabaya: Dunia Ilmu, 2000), cet. Ke-II..h. 373-374. 


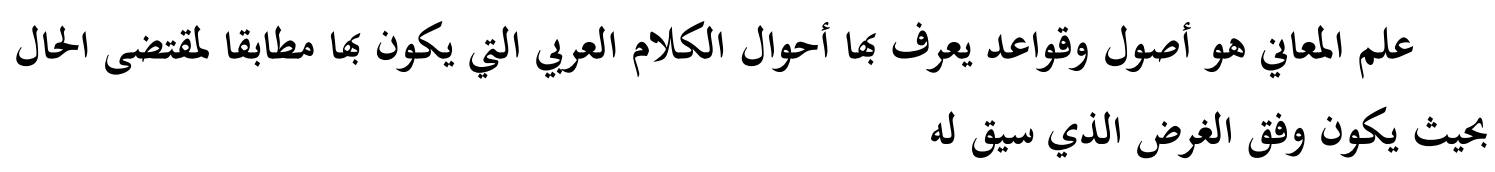

"Ilmu Ma'ani ialah ketentuan-ketentuan pokok dan kaidah-kaidah yang dengannya diketahui ihwal keadaan kalimat Arab yang sesuai dengan keadaan dan relevan dengan tujuan pengungkapannya".

b). Ilmu Bayan, yang membahas segi makna lafal yang beragam. Definisinya yaitu :

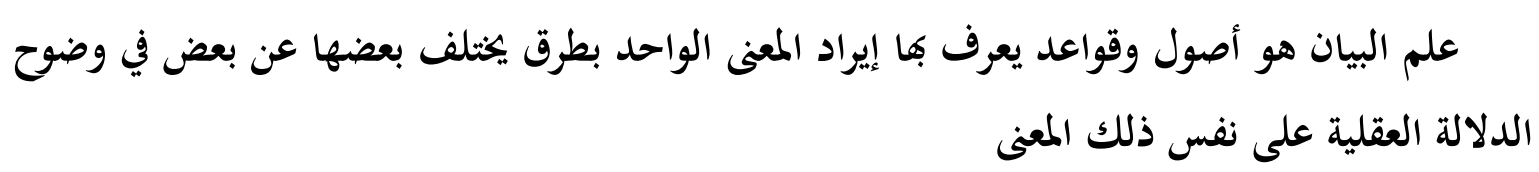

"Ilmu Bayan ialah beberapa ketentuan pokok dan kaidah yang dengannya dapat diketahui penyampaian makna yang satu dengan berbagai ungkapan, namun terdapat perbedaan kejelasan tunjukan makna antara satu ungkapan dengan ungkapan lainnya yang beragam tersebut"

c). Ilmu Badi’, yang membahas keindahan kalimat Arab. Definisinya yaitu:

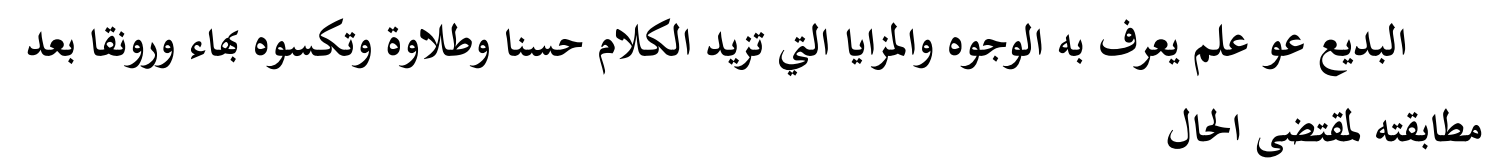

"Ilmu Badi' ialah suatu ilmu yang dengannya dapat diketahui bentuk-bentuk dan keutamaan-keutamaan yang dapat menambah nilai keindahan dan estetika suatu ungkapan, membungkusnya dengan bungkus yang dapat memperbagus dan mepermolek ungkapan itu, disamping relevansinya dengan tuntutan keadaan".

Ilmu bayan berasal dari bahasa arab yang artinya "kias" atau "kiasan", dalam Kamus Besar Bahasa Indonesia berarti antara lain :

1. Perbandingan, persamaan dan ibarat

2. Sindiran

3. Analogi

Jadi uslub atau gaya bahasa kiasan yang dibahas dalam ilmu bayan pada dasarnya dibentuk berdasarkan perbandingan dengan analogi, yakni membandingkan suatu benda atau suatu keadaan dengan benda atau keadaan lain, karena keduanya memiliki hubungan kesamaan atau hubungan lain seperti hubungan sebab akibat, hubungan tempat dan lain sebagainya. Sedangkan arti bayan itu sendiri yaitu الكشف والايضاح (mengungkapkan, menjelaskan),

Firman Allah SWT:

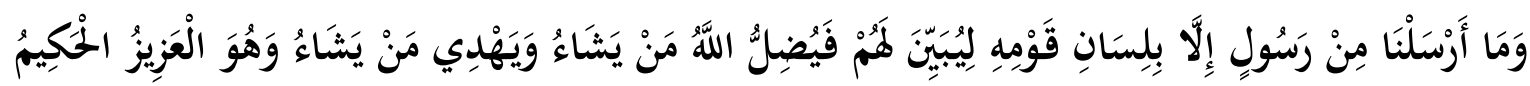

Artinya: "Kami tidak mengutus seorang rasulpun, melainkan dengan bahasa kaumnya supaya ia dapat memberi penjelasan dengan terang kepada mereka". ${ }^{20}$

20Q.S. Ibrahim: 4. 
Maksudnya menjelaskan satu makna dengan berbagai ungkapan atau berbagai uslub, apakah dengan uslub التشبيه (perumpamaan) atau dengan uslub الاستعارة (metafora, personifikasi) atau dengan uslub kiasan lainnya, tergantung kepada situasi dan kondisi.

Sedangkan Al-bayan menurut istilah ilmu balaghah adalah :

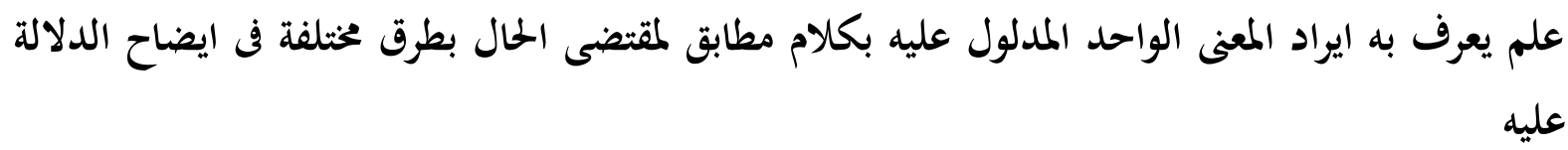

Artinya : Ilmu bayan ialah ilmu untuk mengetahui tentang cara mendatangkan suatu pengertian yang ditunjukan atasnya dengan perkataan yang muthobaqoh (sesuai) dengan muqtadhol-halnya dan dengan susunan yang berbeda-beda dalam menjelaskan dilalahnya. ${ }^{21}$

\section{B. Ruang Lingkup Ilmu Bayan}

Para Ahli balaghah, sepakat bahwa kajian dalam Ilmu Bayan, mencakup tiga hal, yaitu: (التشبية) At-Tasybih (الكجازية) Al-majaz dan (الكجاز) Al-kinayah. ${ }^{22}$

1. التشبيه (gaya bahasa simile)

Dalam kamus Al-munawir, lafadz التمثيل التشبيه dan dalam bahasa Indonesia berarti "persamaan".

Sedangkan menurut istilah Ilmu balaghah:

$$
\text { التشبيه هو إلحاق امر بامر بادة التشبيه لجامع بينهما }
$$

"Yaitu menyamakan suatu hal dengan hal lain dengan menggunakan perangkat (sarana) tasybih untuk mengumpulkan diantara keduanya". ${ }^{23}$

Secara etimologis, al-tasybih berarti al-tamtsil (penyerupaan). Sedangkan secara terminologis adalah menyerupakan antara dua perkara atau lebih yang memiliki kesamaan sifat (satu atau lebih) dengan suatu alat: karena ada tujuan yang dikehendaki oleh pembicara. ${ }^{24}$

Suatu ungkapan yang menyatakan bahwa sesuatu itu mempunyai kesamaan dengan yang lainnya dalam sifat, dalam menyamakan tersebut menggunakan sarana atau perangkat, baik secara eksplisit maupun implisit.

Rukun-rukun At-tasybih ada 4, yaitu:

a) Musyabbah (المشبة) : sesuatu yang di perbandingkan.

b) Musyabbah bih (المشبة بهة) : Objek yang diperbandingkan.

Gabungan antara Musyabbah dan Musyabbah bih disebut Tharafai tasybih (طرفي التشبيه).

c) Adat At-tasybih(أداة التشبيه)

Yaitu suatu lafadz yang menunjukkan adanya persamaan (antara dua hal atau lebih), serta mendekatkan musyabbah pada musyabbah bih dalam sifatnya. ${ }^{25}$ atau bisa dikatakan Sarana atau perangkat untuk menyamakan. Sedangkan Adat At-tasybih ada tiga macam: pertama dari huruf, yaitu: كان (الكف, kedua: dari isim, yaitu, مثل, مشابة, نحو, مماثل, dan ketiga: dari

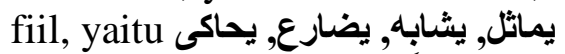

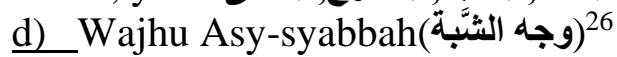

21 D. Hidayat, Al-Balaghotu lil Jami', (Jakarta: PT. Karya Toha Putra, 2002), h. 112.

22 Muhammad Yasin bin 'Isa Al-Fadani, Hasan As-Shiyaghah, (Al-Barakah, 2007), h. 86.

23 Fadhil Hasan ‘Abbas, Al-Balaghah Fununiha wa Afnaniha, (Al-Irdan: Daar Al-Furqan, 1986), h. 17.

24[5] Ahmad al-Hasyimiy, Jawahir al-Balaghah fi al-Ma 'aniy wa al-Bayan wa al-Badi', (Maktabah Daar Ihya alKutub al-'Arabiyyah, 1960), h. 246.

25 Mardjoko Idris, Ilmu Balaghah antara Al-bayan dan Al-Badi', (Yogyakarta: Teras, 2007), h. 13.

26 Ahmad Qalas, Taisir Al-Balaghah, (Jeddah: Mathba'ah Ats-Tsighr, 1995), h. 69. 
Yaitu makna atau sifat yang dimiliki oleh musyabbah dan musyabbah bih atau Bentuk kesamaan sifat yang disamakan antara Musyabbah (المشبة) dan Musyabbah bih (المشبة به). Adapun untuk lebih jelasnya mari kita amati contoh dibawah ini:

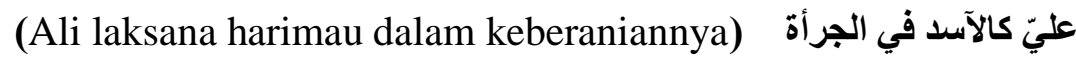

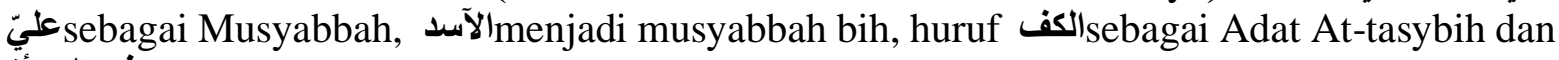
في الجرأة

Contoh At-tasybih dalam Al-qur'an adalah:

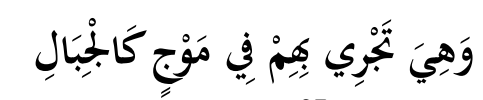

“Dan bahtera itu berlayar membawa mereka dalam gelombang laksana gunung. "27

2. المجاز (gaya bahasa metafora)

Pengertian Majaz menurut istilah Ilmu balaghah:

$$
\text { الجماز هو اللفظ المستعمل في غير ما وضع له لعلاقة مع قرينة مانعة من إرادة المعنى الساب }
$$

"Majaz adalah yang digunakan tidak pada tempatnya, karena ada keterkaitan serta alasan yang mencegah dari makna terdahulu”.

Macam-macam Majaz ada 2, yaitu:

a) Majaz 'aqly

$$
\text { يكون في الاسناد, اي في اسناد الفعل او ما في معناه المى غير ما هوله }
$$

"Majaz Aqly adalah majaz yang terjadi pada penyandaran fi'il pada fa'il yang tidak sebenarnya".

b) Majaz Lughawy

Pengertian majaz Lughawy menurut istilah adalah:

الجماز اللغوي هو كلمة استعملت في غير ما وضعت له لعلاقة مع قرينة تمنع من إرادة المعنى الحقيقيي

"Majaz Lughawy adalah kata yang digunakan tidak pada tempatnya, karena ada keterkaitan serta alasan yang mencegah dari makna hakiki".

Adapun Pembagian Majaz Lughawy ada 2, yaitu:

1) Isti'arah (peminjaman kata)

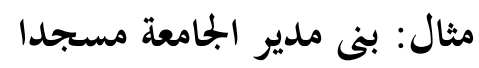

الاستعارة هي مجاز علاقته المشابكة "Istiarah adalah majan

"Istiarah adalah majaz yang mempunyai hubungan langsung"

Konsep isti'arah sebenarnya bermuara dari bentuk gaya bahasa tasybih, dan gaya bahasa isti'arah adalah ungkapan tasybih yang paling tinggi.28[9] Menurut mayoritas ahli balaghah gaya bahasa isti'arah mempunyai tiga unsur; 1. musta'ar lah (musyabbah), 2. musta'ar minhu (musyabbah bih), dan 3. musta'ar (kata yang dipinjam).

\section{Q.S. Hud: 44.}

28 Bakri Syaikh Amin, Al-Balaghah al-'Arabiyah fi Tsaubiha al-Jadid al-Bayan, juz.II, (Beirut: Dar 'Ilm li alMalayin, 1995), h. 18 
Contohnya:

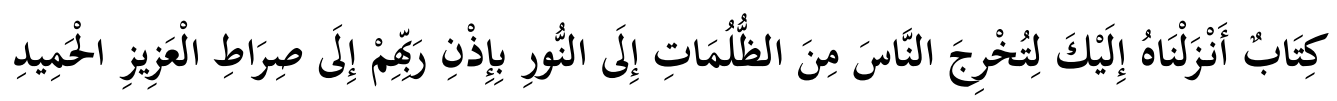

"(ini adalah) kitab yang Kami turunkan kepadamu supaya kamu mengeluarkan manusia dari gelap gulita kepada cahaya terang benderang dengan izin Tuhan mereka, (yaitu) menuju jalan Tuhan yang Maha Perkasa lagi Maha Terpuji “. ${ }^{29}$

Pada contoh kalimat diatas, lafadz majazinya adalah الظََُُْْاتِ yang berarti kegelapan, dan النُورِ $y$ yang berarti cahaya. Benarkah Al-qur'an dapat mengeluarkan manusia dari kegelapan ke alam yang terang benderang? Tentu tidak, karena yang dimaksud Allah dalam firmannya bukanlah makna hakiki, melainkan makna majazinya, yaitu الضلالة), yang artinya kesesatan dan الهُى إlpetunjuk.

Kata "nur" di sini dipinjam untuk memperjelas misi dan pesan kenabian, karena keduanya memiliki fungsi meyakinkan, menghilangkan, serta menepis keraguan atas kebenaran misi kenabian tersebut. Jadi maksud kata "al-nur" adalah kehadiran Nabi Muhammad saw.

2) Majaz Mursal.

$$
\text { مجاز المرسال هو مجاز تكون علاقة بين المعنى الحقيقة و الجحازى قائمة غير المشابمة }
$$

"Majaz Mursal adalah majaz yang hubungan antara makna hakiki dan makna majazi merupakan hubungan yang tidak langsung”

Contoh:

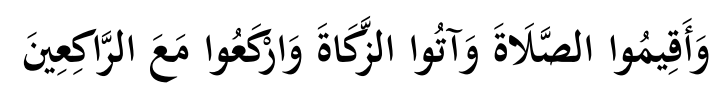

"Dan dirikanlah shalat, tunaikanlah zakat dan ruku'lah beserta orang-orang yang ruku' '، 30

Yang dimaksud oleh Allah dalam ayat tersebut adalah makna majazi, bukan makna hakiki, yaitu: shalat berjama'ah dan dapat pula diartikan: tunduklah kepada perintah-perintah Allah bersama-sama orang-orang yang tunduk.

3. الكناية (gaya bahasa mitonimie)

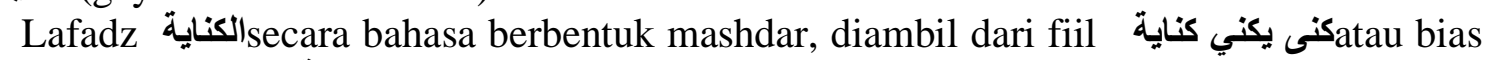
juga masdar dari fiil كنا يكنو كناية yang berarti menerangkan sesuatu dengan perkataan yang lain, mengatakan dengan kiasan, atau sindiran.

Sedangkan pengertian الكنايةmenurut istilah Ilmu balaghah adalah:

$$
\text { الكناية هو لفظ أطلق و أريد به لازم معنه مع جواز إرادة المعنى الآصلى }
$$

Artinya: lafadz yang disampaikan dan yang dimaksud adalah kelaziman maknanya, disamping boleh juga yang dimaksud pada arti yang sebenarnya. ${ }^{31}$

Contohnya:

$$
\text { نزلنا على رجل كثير الرماد }
$$

Artinya: "kita mampir pada seorang laki-laki yang banyak abu dapurnya".

29 Q.S. Ibrahim: 1.

30 Q.S. Al-baqoroh: 43.

31 Abu Hilal Al-'Askary, Al-Balaghah Al- 'Arabiyyah fi Tsaubiha Al-Jadid, (Beirut: Daar Al-'Ilm, 1996), h. 46. 
Dalam kalimat tersebut terdapat ungkapan كثير الرماد, yang berarti abu dapur, makna yang dimaksud dalam kalimat tersebut bukanlah makna sebenarnya, yakni abu dapur, tetapi makna lain yang menjadi kelazimannya. Makna Yang dikehendaki dari kalimat كثير الرماد orang yang banyak abu dapurnya, kelazimanya banyak memasak, orang yang banyak memasak itu kelazimannya banyak menjamin makanan dan minuman, orang yang banyak menjamu tamu itu kelazimannya banyak tamu, orang yang banyak tamu kelazimannya baik hati, dermawan, kharismatik atau dihormati dan disegani.

Jadi untuk mengatakan bahwa seseorang itu dermawan, seseorang tidak mengatakan هو melainkan dengan kalimat هو كثير الرماد , suatu lakimat yang disampaikan namun yang dimaksud adalah makna lain, itulah yang dalam Ilmu bayan dinamakan Al-kinayah (الرمال هثناية).

Contoh kinayah dalam Al-qur'an:

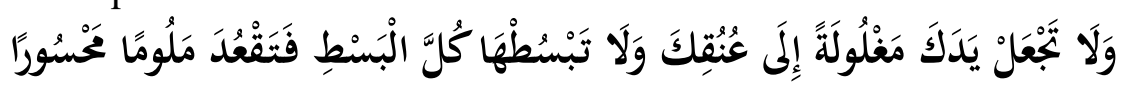

"Dan janganlah kamu jadikan tanganmu terbelenggu pada lehermu dan janganlah kamu terlalu mengulurkannya karena itu kamu menjadi tercela dan menyesal". ${ }^{33}$

Maksudnya: jangan kamu terlalu kikir, dan jangan pula terlalu Pemurah.

\section{Peletak Dasar Ilmu Bayan}

llmu Bayan pertama kali dikembangkan oleh Abu Ubaidah lbn al-Matsani $(211 \mathrm{H})$. sebagai dasar pengembangan irmu ini, ia menulis sebuah kitab dengan judul Mazaj Qur'an. Dalam perkembangan berikutnya muncul pula seorang tokoh terkemuka dalam ilmu ini, yaitu; Abd al-Kahir al-Jurzini (471 M). llmu ini terus berkembang dan disempurnakan oleh para ulama berikutnya, sepeti al- Jahizh ibn Mu'taz, Quddamah, dan Abu Hilal al-Askari. ${ }^{34}$

\section{Manfaat mempelajari Ilmu Bayan}

Objek kajian ilmu bayan adalah tasybih, majaz, dan kinayah, Melalui ketiga bidang ini kita akan mengetahui ungkapan-ungkapan bahasa Arab yang fasih baik dan benar, serta mengetahui ungkapan-ungkapan yang tidak fasih dan tidak cocok untuk diucapkan. llmu ini dapat membantu kita juga untuk mengungkapkan suatu ide atau perasaan melalui bentuk kalimat dan ushlub yang bervariasi sesuai dengan muqtadha al-hal.

Dengan pengetahuan di atas, seseorang bahkan akan mampu menangkap kemukjizatan al-Qur'an dari aspek bahasanya. Dengan kata lain, lewat kemampuan yang memadai pada ilmu ini seseorang akan mampu menangkap keindahan, ketepatan,dan kehebatan ayat al-qur'an, baik pada tataran jumlah, kalimah, sampai kepada huruf-hurufnya. ${ }^{35}$

\section{Kedua : Lebih Dekat dengan Al-Baidhawy}

Al-Baidawi dilahirkan di Baida', sebuah daerah yang berdekatan dengan kota Syiraz di Iran Selatan. Di kota inilah beliau tumbuh dan berkembang menempa ilmu. Ia juga pernah belajar di Baghdad hingga kemudian menjadi hakim agung di Syiraz (Azarbaijan) -suatu daulah yang berdiri sendiri namun tetap berkiblat kepada daulah Abbasiyah -mengikuti jejak

\footnotetext{
32 Ghufran Zainul Alim, Jawahir Al-Balaghah, (Bandung: Sinar baru Al-gesindo, 2010), hlm. 75

33 Q.S. Al-Isra': 29.

34[15] Mamat Zaenuddin dan Yayan Nurbayan, Pengantar Ilmu Balaghah, (Bandung: PT. Refika Aditama, 2007), h. 16.

35[16] Ibid.
} 
ayahnya. ${ }^{36}$ Abdullah ibn Umar bin Muhammad bin Ali al-Baidawi al-Syafi'i yang merupakan nama lengkap dari al-Baidawi adalah seorang ulama multidisipliner dalam ilmu pengetahuan, yaitu ahli dalam bidang tafsir, bahasa arab, fiqh, ushul fiqh, teologi, dan mantiq. ${ }^{37}$ Iapun merupakan sosok yang pandai berdebat dan sangat menguasai etika berdiskusi, sehingga pantaslah ia mendapatkan gelar nazzar atau mutabahhir fi maida fursan al-kalam. ${ }^{38}$ AlBaidhawi merupakan salah satu pengikut madzhab syafi'iyah dalam bidang fiqh dan ushul fiqh serta menganut konsep teologi ahl al-sunnah wa al-jama'ah.

Sesuai dengan jabatan dan keahliannya dalam berbagai bidang keilmuan, al-Baidawi dapat disebut sebagai sosok yang unggul dalam masyarakatnya. Salah satu bukti kepandaiannya adalah pujian yang diteriama beliau, yaitu Nasir al-Din (penolong agama). AlBaidawi hidup dalam keadaan politik yang tidak menentu. Sultan Abu Bakar yang memegang tampuk kekuasaan pada saat itu tidak memiliki kekuatan yang cukup untuk membangun tatanan masyarakat yang baik. Bukan hanya supremasi keadilan yang lemah, namun juga sikap hedonis dan boros dari para pejabat yang berkuasa. Nampaknya hal inilah yang melatarbelakangi pengunduran diri al-Baidawi dari jabatan hakim agung. Intervensi dari penguasa terhadap lembaga peradilan yang begitu kuat membuat kekhawatiran tersendiri bagi banyak fuqaha', termasuk al-Baidawi. Mereka khawatir jika diperintah untuk mengeluarkan fatwa yang bertentangan dengan syari'at Islam. Keputusan al-Baidawi ini juga dipengaruhi oleh nasihat yang diberikan oleh pembimbing spiritualnya, Syaikh Muhammad bin Muhammad al-Khata'i agar al-Baidawi tidak lagi bersentuhan dengan lembaga hukum. ${ }^{39}$

Setelah melepaskan jabatannya sebagai hakim di daerah Syiraz, al-Baidawi mengembara ke Tabriz dan berguru pada ulama setempat. Ia singgah di sebuah majlis dars bagi para pembesar setempat. Karena kehebatan beliau, banyak diantara pembesar setempat memujinya. Dikota inilah beliau mengarang kitab tafsir yang berjudul Anwar al-Tanzil wa Asrar al-Ta'wil. Beliau menetap di kota ini hingga ajal menjemputnya. Ada perbedaan diantara ulama tentang tahun wafat beliau, antara lain al-Subki dan Asnawi menyatakan bahwa al-Baidawi wafat pada tahun $691 \mathrm{M}$, sedangkan Ibnu Kasir menyatakan bahwa beliau wafat tahun 685 M. ${ }^{40}$

Sebagai seorang ulama yang terkemuka, al-Baidawi telah menghasilkan banyak karya tulis diberbagai bidang keilmuan. Karya-karya tesebut antara lain Anwar al-Tanzil wa Asrar al-Ta'wil (tafsir), Syarah Masabih (hadis), Tawali al-Anwar, al-Misbah fi Ushul al-Din (teologi), syarh al-Mahsul, Minhaj al-Wusul ila 'Ilm al-Usul (ushul fiqh), syarh al-Tanbih (fiqh), al-Lubb fi al-Nahwu (nahwu), Kitab Al-Mantiq (mantiq), al-Tahzib wa al-akhlaq (tasawuf), Nizam al-Tawarikh (sejarah), dll. ${ }^{41}$

36 Muhammad Yusuf (dkk), Studi Kitab Tafsir; Menyuarakan Teks yang Bisu, (Yogyakarta: Teras, 2004), hlm. 114-115.

37 Haji Khalifah, Kasyf al-Zunun, (Beirut: Dar al-Fikr, 1994), hlm. 197.

38 Haji Khalifah, Kasyf al-Zunun, (Beirut: Dar al-Fikr, 1994), hlm. 197.

39 Muhammad Yusuf (dkk), Studi Kitab Tafsir; Menyuarakan Teks yang Bisu, (Yogyakarta: Teras, 2004), hlm. 197.

40 Husain al-Dzahabi, Al-Tafsir wal Mufassirun, (Maktabah Mush'ab bin Amir al-Islamiyah, 2004), hlm. 211.

41 Muhammad Yusuf (dkk), Studi Kitab Tafsir; Menyuarakan Teks yang Bisu, (Yogyakarta: Teras, 2004), 


\section{METODE PENAFSIRAN AL-BAIDHAWI}

Anwar at-Tanzil wa Asrar at'Ta'wil, itulah judul dari tafsir yang ditulis oleh alBaidhawi, dan lebih dikenal dengan tafsir al-Baidhawi. Tafsir ini merupakan salah satu kitab yang populer di dunia Islam, yang memiliki banyak manfaat, gaya bahasa yang indah, perumpamaan yang manis, dan banyak diminati para pakar dan cendekiawan terkemuka untuk mengkaji dan memberi catatan pinggir (komentar) terhadapnya, hingga tercatat sebanyak 83 buah kitab yang berisi hal itu. Dan, kitab yang terkenal memberikan catatan pinggir terhadap Tafsir al-Baidhawi di antaranya adalah catatan pinggir Syekh Zadah dan Syihab al-Khaffaji ('Inâyat al-Qâdhi).

Karyanya ini seolah-olah merupakan ringkasan dari tafsir al-Kasysyaf karya azZamakhsyari. Namun al-Baidhawi tidak mengikuti pemikiran-pemikiran dari az-Zamakhsyari yang satu satu sisi seperti cenderung bernuansa Mu'tazilah yang banyak menggunakan akal dan nalar, karena al-Baidhawi seorang yang bermazhab Asy’ariyah.

Kitab ini juga tidak terhindar dari hadis-hadis dha'if, dan cerita israiliyat walau sangat minim, khususnya pada pembahasan akhir surat tentang keutamaannya. Isinya dibuat semodel ringkasan (ikhtishâr), mengandung berbagai pemikiran, pandangan-pandangannya diarahkan pada banyak dimensi gramatika bahasa, fiqh, dan ushul yang terkandung dalam ayat-ayat al-Quran, dan begitu juga dari sudut pandang bacaan (qirâat) dan makna intrinsik ayat (isyârât), serta mengkombinasikan antara tafsir dan takwil berdasarkan kaidah-kaidah bahasa dan syar'i. Metode penafsirannya dibuat sebagaimana umumnya kitab-kitab tafsir, menyebutkan nama surat, mengaitkan dengan konteks turunnya, baru menafsirkan ayat demi ayat, serta mengangkat hadis tentang keutamaannya pada akhir surat tersebut. ${ }^{42}$

Pemilik kitab al-Kasyaf adz-Dzunnun Al-Mishry berkata, "Tafsir al-Baidhawi adalah kitab yang mulia, tidak butuh penjelasan lagi, ia merangkum dari kitab al-Kasyaf, yang berkaitan dengan i'rab, ma'ani, dan bayan. Dari tafsir kabir karya ar-Razi dia merangkum yang berkaitan dengan hikmah dan ilmu kalam, dari tafsir al-Raghib yang berkaitan dengan pengambilan kata dan rumitnya kebenaran-kebnaran serta kehalusan isyarat. Ia menghimpun kerangka-kerangka pemikirannya dengan rasional. Dengan demikian, tersingkaplah kotoran keraguan dari rahasia-rahasia, dan ilmu semakin bertambah luas. Oleh karenanya, Maulana alMunsyi berkomentar "Para cendekiawan tidak datang, dengan menyingkap cadar (Qina') dari apa yang dibaca, tetapi al-Baidhawi memiliki tangan yang putih berkilau tanpa cacat, karena ia orang yang menguasai medan kemahiran bicara. ${ }^{43}$

Tafsir al-Baidhawi adalah tafsir ra'yu, karena, dalam menafsirkan dia sangat memperhatikan hadis-hadis yang berasal dari Rasulullah dan sangat waspada terhadap riwayat-riwayat yang dha'if dan maudhu'. Berpegang pada ucapan sahabat Nabi, karena apa yang mereka katakan, menurut peristilahan hadis hukumnya mutlak marfu' (shahih atau hasan), khususnya yang berkaitan dengan asbabunnuzul, dan berpegang pada kaidah bahasa arab dan berpegang pada maksud ayat, dan harus terjamin kebenarannya menurut aturan dan hukum syara'.

Al-Baidhawi sangat menaruh perhatian kepada penyajian dalil-dalil berdasarkan pokok-pokok pemikiran ahlus-sunnah wal jama'ah, di samping perhatiannya kepada kaidahkaidah bahasa (arab). Tapi ia tidak selalu tetap dalam meriwayatkan hadis-hadis pada akhir

42 Husain al-Dzahabi, Al-Tafsir wal Mufassirun, (Maktabah Mush'ab bin Amir al-Islamiyah, 2004).

43 Husain al-Dzahabi, Al-Tafsir wal Mufassirun, (Maktabah Mush'ab bin Amir al-Islamiyah, 2004), hlm. 211. 
tiap surah untuk menjelaskan keutamaannya. Sebagian besar hadis-hadis yang diriwayatkan bukan hadis-hadis sahih.

Contoh sebagian tafsir Al-Baidhawy;

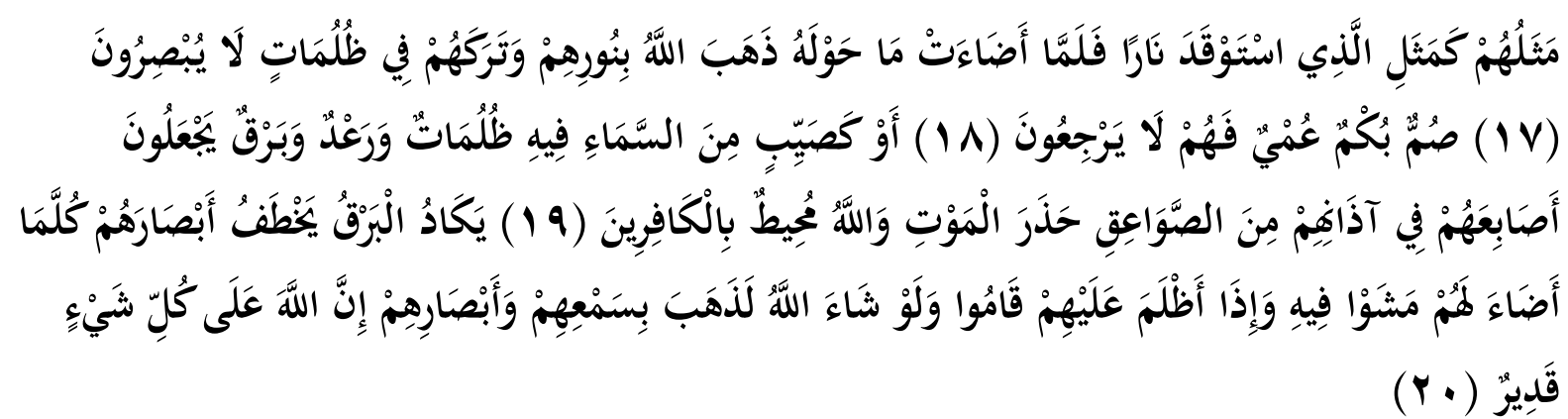

Perumpamaan mereka adalah seperti orang yang menyalakan api ${ }^{44}$, maka setelah api itu menerangi sekelilingnya Allah hilangkan cahaya (yang menyinari) mereka, dan membiarkan mereka dalam kegelapan, tidak dapat melihat

Mereka tuli, bisu dan buta ${ }^{45}$, maka tidaklah mereka akan kembali (ke jalan yang benar),

Atau seperti (orang-orang yang ditimpa) hujan lebat dari langit disertai gelap gulita, guruh dan kilat; mereka menyumbat telinganya dengan anak jarinya, karena (mendengar suara) petir,sebab takut akan mati ${ }^{46}$. Dan Allah meliputi orang-orang yang kafir ${ }^{47}$.

Dalam suatu riwayat dikemukakan, bahwa dua orang munafiq Madinah lari dari Rasulullah kepada kaum musyrikin. Di jalan ditimpa hujan (sebagaimana diterangkan dalam Surat Al-Baqarah[2]: 19, 20, bahwa hujan tersebut mengandung guruh yang dahsyat, petir dan kilat). Tiap kali ada petir mereka menutup telinganya dengan jari, karena takut memekakkan telinganya, dan mati karenanya. Apabila kilat bersinar, mereka berjalan. Dan apabila tiada sinar kilat, mereka tidak dapat melihat. Mereka kembali ke jalan semula untuk pulang dan menyesali perbuatan mereka dan keesokan harinya mereka menghadap kepada Rasulullah SAW menyerahkan diri masuk Islam dengan sebaik-baiknya. Allah mengumpamakan kejadian dua orang munafiq ini kepada kaum munafiqin lainnya yang ada di Madinah. Apabila menghadiri majlis Rasulullah SAW mereka menutup telinga dengan jarinya karena takut terkena oleh sabda Rasulullah SAW yang meneragnkan hal ihwal mereka sehingga terbongkarlah rahasianya, atau mereka jadi tunduk, karena terpikat hatinya. Perbandingan antara kedua orang munafiq dengan munafiqin Madinah ialah:

1. Kedua orang munafiq menutup telinganya karena takut mendengar guruh yang memekakkan, dan apabila kilat bersinar mereka berjalan. Sedang kaum munafiqin Madinah menutup telinga karena takut terkena sabda Rasul. Akan tetapi di saat banyak harta, anak buah

44 Orang-orang munafik itu tidak dapat mengambil manfaat dari petunjuk-petunjuk yang datang dari Allah, karena sifatsifat kemunafikkan yang bersemi dalam dada mereka. Keadaan mereka digambarkan Allah seperti dalam ayat tersebut di atas

45 Walaupun pancaindera mereka sehat mereka dipandang tuli, bisu dan buta oleh karena tidak dapat menerima kebenaran.

46. Keadaan orang-orang munafik itu, ketika mendengar ayat-ayat yang mengandung peringatan, adalah seperti orang yang ditimpa hujan lebat dan petir. Mereka menyumbat telinganya karena tidak sanggup mendengar peringatan-peringatan Al Quran itu. (Al-Quran dan Terjemahnya, Kemerntian agama RI. Elektronik.)

47 Maksudnya pengetahuan dan kekuasaan Allah meliputi orang-orang kafir. (Al-Quran dan Terjemahnya, Kemerntian agama RI. Elektronik.) 
dan mendapat ghanimah atau kemenangan, mereka ikut serta dengan kaum Muslimin dan berkata: "Nyatalah sekarang benarnya agama Muhammad itu." Dan mereka merasa tentram.

2. Kedua orang munafiq apabila tiada cahaya kilat, mereka berhenti dan tertegun. Sedang kaum munafiqin Madinah apabila habis hartanya, anak buahnya dan terkena musibah, mereka berkata: "Inilah akibat agama Muhammad." Mereka kembali murtad dan kufur.

(Diriwayatkan oleh Ibnu Jarir dari abi Shaleh yang bersumber dari Ibnu Abbas, Murrah, Ibnu Mas'ud dan beberapa orang shahabat lainnya.) ${ }^{48}$

Perumpamaan mereka (orang2 Munafik) itu seperti menyalakan api , Al-Baidhawi menjelaskan; Arti kata "Matsal" pada ayat diatas : adalah "An Nadhir", yang berarti perbandingan,-maksudnya, prilaku orang-orang munafik itu adalah sesuatu yang aneh, Allah SWT mengumpamakan mereka seperti orang yang menyalakan api, maka setelah api itu menerangi sekelilingnya Allah hilangkan cahaya (yang menyinari) mereka, dan membiarkan mereka dalam kegelapan, tidak dapat melihat.

Kegelapan yang dimaksud dalam ayat ini adalah gelapnya kekafiran dan kemunafikan serta akan gelapnya mereka pada hati kiamat seperti pada firman Allah;

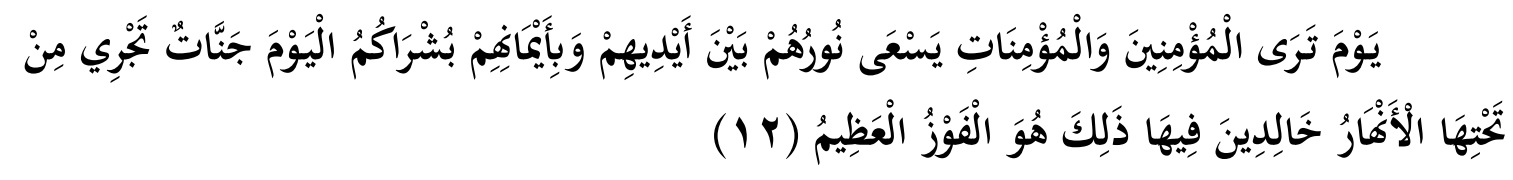

(Yaitu) pada hari ketika kamu melihat orang mukmin laki-laki dan perempuan, sedang cahaya mereka bersinar di hadapan dan di sebelah kanan mereka, (dikatakan kepada mereka): "Pada hari ini ada berita gembira untukmu, (yaitu) syurga yang mengalir di bawahnya sungaisungai, yang kamu kekal di dalamnya. Itulah keberuntungan yang besar." (QS AlHadid[57]:12)

Atau yang dimaksud adalah gelapnya kesesatan, dan gelapnya murka Allah SWT, serta gelapnya azab Allah, atau kegelapan yang teramat sangat sehingga seolah-olah gelapnya bertingkat.

Perumpamaan ini adalah bagi mereka yang telah kedatangan petunjuk, lalu mereka menyia-nyiakannya, sehingga mereka tidak pernah sampai pada kenikmatan abadi, sehinggga kondisi mereka berada dalam kebingungan dan kerugian. Secara umum, orang-orang munafik juga termasuk di dalamnya, karena mereka menyia-nyiakan apa yang mereka sendiri mengucapkannya, kebenaran yang mereka ucapkan, namun kekufuran yang mereka jalankan.

Selanjutnya pada ayat;

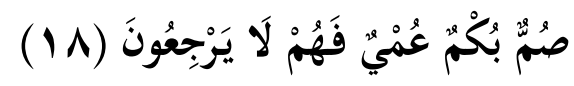

Mereka tuli, bisu dan buta ${ }^{49}$, maka tidaklah mereka akan kembali (ke jalan yang benar).

48 Al-Quran dan Terjemahnya, Kemerntian agama RI. Elektronik.

49 Walaupun pancaindera mereka sehat mereka dipandang tuli, bisu dan buta oleh karena tidak dapat menerima kebenaran. 
Kalimat ini adalah kalaimat perumpamaan, bukan metafora atau simbolik, karena tidak ada sesuatu yang menunjukkan akan hal tersebut. Jadi Walaupun pancaindera mereka sehat, mereka dinilai dan dipandang seperti orang yang tuli, bisu dan buta oleh karena tidak dapat menerima kebenaran, karena memang mereka sendirilah yang tida mau menerimanya.

\section{PENUTUP}

Sebagai kesimpulan dari tulisan ini adalah, bahwa meskipun dikatakan bahwa Tafsir Al-Baidhary merupakan ringkasan dari tafsir Al-Kasy-syaf karya al-Zamakhsyary, sebagaimana diakui sendiri oleh sang penulisnya, namun dalam hal sisi Balaghanya, AlBaidhawy tidak terlalu mengumbar pemaparan, karena sisi Balaghah bukanlah tujuan yang beliau utamakan, melainkan lebih kepada bagaimana Al-Baidhawy memperjelas kandungan makna ayat demi ayat dalam al-Quran. Wallahu A'lam. 


\section{DAFTAR PUSTAKA}

- Abbas, Fadhal Hasan, Al-Balaghah Fununuha Wa Afnanuha, 'Amman: Dar AlFurqan, 1987.

- Al-Jarimi, Ali dan Musthafa Amin, Al-Balaghah Al-Wadhihah, Dar Al-Ma'arif, 1999.

- Al-Maidani, Abdurrahman Hasan, Al-Balaghah Al-Arabiyah Ususuha Wa 'Ulumuha Wa Fununuha, Damaskus: Dar Al-Qalam, 1997.

- Al-Qazwini, Al-Khatib, Al-Idhah Fi 'Ulum Al-Balaghah Al-Ma'ani Wa Al-Bayan Wa Al-Badi', Beirut: Dar al-Kutub al-Ilmiyah, 2010.

- Idris, Mardjoko, Ilmu Balaghah Antara Al-Bayan dan Al-Badi', Yogyakarta: Penerbit Teras, 2007.

- Iman, Maman Dzul, Menyingkap Rahasia Balaghah dalam Karya Al-Barzanjiy, Yogyakarta: Deepublish, 2013.

- Tafsir al - Baidhawy

- Terjemah Al-quran Kementrian agama

- Kamus Al-Munawwir

- Kamus Besar Bahasa Indonesia 